\title{
Mutations in the melanocortin-1 receptor $(M C 1 R)$ gene have no influence on the distinct patterns of melanic plumage found in the manakins of the genus Antilophia (Aves: Pipridae)
}

\author{
LEILTON W. LUNA ${ }^{1,2}$, WEBER A. GIRÃO E SILVA ${ }^{3}$, JULIANA ARARIPE ${ }^{1}$, ISADORA T.F. PEREIRA ${ }^{4}$, \\ FERNANDO M. D'HORTA ${ }^{5}$, IRACILDA SAMPAIO ${ }^{6}$, HORACIO SCHNEIDER ${ }^{6}$ and PÉRICLES S. DO RÊGO ${ }^{1}$ \\ ${ }^{1}$ Laboratório de Genética e Conservação, Instituto de Estudos Costeiros, Universidade Federal \\ do Pará, Alameda Leandro Ribeiro, s/n, Aldeia, 68600-000 Bragança, PA, Brazil \\ ${ }^{2}$ Programa de Pós-Graduação de Zoologia, Universidade Federal do Pará/Museu Paraense Emílio \\ Goeldi, Avenida Perimetral, 1901/1907, Perimetral, 66040-170 Belém, PA, Brazil \\ ${ }^{3}$ Associação de Pesquisa e Preservação de Ecossistemas Aquáticos, Avenida José \\ Alencar, 150, Iparaná, 61627-210 Caucaia, CE, Brazil \\ ${ }^{4}$ Pontifícia Universidade Católica do Rio Grande do Sul, Avenida Ipiranga, 6681, Paternon, 90619-900 Porto Alegre, RS, Brazil \\ ${ }^{5}$ Instituto de Biociências, Universidade de São Paulo, Rua do Matão, 14, Butantã, 05508-090 São Paulo, SP, Brazil \\ ${ }^{6}$ Laboratório de Genética e Biologia Molecular, Instituto de Estudos Costeiros, Universidade Federal \\ do Pará, Alameda Leandro Ribeiro, s/n, Aldeia, 68600-000 Bragança, PA, Brazil
}

Manuscript received on December 10, 2017; accepted for publication on February 19, 2018

\begin{abstract}
The melanocortin-1 receptor gene is the most widely-used marker for the investigation of the genetic determination of melanic plumage patterns. Studies of a number of wild bird species have shown an association between non-synonymous mutations of the $M C 1 R$ gene and the presence of melanic variants. The genus Antilophia (Pipridae) includes only two manakin species (A. galeata and A. bokermanni), which are distinguished primarily by the differences in the pattern of melanic coloration of the plumage of the mantle in the adult males. In A. galeata, this plumage is black, while in A. bokermanni, it is predominantly white. This study investigates the possible association between mutations of the MC1R marker and the variation in plumage coloration observed in the two species. The $M C 1 R$ sequences of the two species was analyzed, and the observed nucleotide variation was compared. Six polymorphic sites were identified, representing seven distinct genotypes. Five of these polymorphic mutations were non-synonymous, but were not related to the different phenotypes. Neutral evolution and the absence of any systematic association between the variants of the MC1R and plumage coloration in the Antilophia species indicate that alternative mechanisms regulate the expression of the coloration of the plumage in the adult males.
\end{abstract}

Key words: candidate gene, manakin, melanism, neutral evolution, plumage color.

\section{INTRODUCTION}

The evolution of plumage coloration in birds may be driven by a range of factors related to both natural

Correspondence to: Péricles Sena do Rêgo

E-mail: periclessena@yahoo.com.br and sexual selection, constituting an important speciation mechanism in many taxonomic groups (Dunn et al. 2015). Part of the variation in plumage color within and between species is known to have a strong genetic component (Mundy 2005, 
Roulin and Ducrest 2013), although the genetic mechanisms involved in this process are still poorly-understood, especially in wild species.

The melanocortin-1 receptor $(M C 1 R)$ gene is the most popular genetic marker for the analysis of melanic patterns in bird plumage (Uy et al. 2009, Bourgeois et al. 2012). In most cases, mutations of the MC1R gene that cause an increase in its receptor activity are dominant, and are associated with black coloration (Bourgeois et al. 2012, Roulin and Ducrest 2013). However, a growing number of studies have shown that variations in the $M C 1 R$ sequence may not always be associated with distinct patterns of coloration in birds (Haas et al. 2009, Bourgeois et al. 2012).

The genus Antilophia is formed by two species of manakin (Pipridae, Passeriformes). The principal difference between the two species - Antilophia galeata and Antilophia bokermanni - is observed in the coloration of the plumage of the adult males. In A. galeata, the cover feathers are black, whereas in A. bokermanni, these feathers are white (Coelho and Silva 1998), contrasting with the black tertial and rectrice flight feathers (Figure 1).

Recent studies have shown that the genetic profiles of the two species are virtually indistinguishable (Rêgo et al. 2010, Luna et al. 2017), and that the mixture of genetic features observed in the two species is likely the result of the incomplete separation of the two lineages following a very recent process of diversification (Luna et al. 2017). In this context, a single mutation in the $M C 1 R$ gene might have resulted in a change in the melanin levels of the feathers (Uy et al. 2009), resulting in a distinct phenotype, which would be fixed rapidly in small populations, such as that of

\section{A. bokermanni.}

In the present study, we investigated whether possible mutations in the codifying region of the $M C 1 R$ gene are associated with the process that determines the difference in the principal phenotypic characteristic that distinguishes the two Antilophia species. To this end, we attempted to resolve two principal questions: 1) Is the inter- and intra-specific variation in the $M C 1 R$ sequences associated directly with the different melanic patterns observed in the plumage of the two Antilophia species? and 2) Does the variation in the $M C 1 R$ nucleotide sequences reflect selection pressures driving the fixation of the non-synonymous mutations that determine the phenotypes of the two species?

\section{MATERIALS AND METHODS}

\section{SAMPLING AND GENETIC SEQUENCING}

Samples of the tissue of $A$. bokermanni $(\mathrm{n}=16)$ were obtained from specimens captured in the northeastern portion of the Chapada do Araripe, in the state of Ceará, Brazil (Figure 2). Samples of the sister species $A$. galeata were obtained from researchers at the Federal University of São Carlos (UFSCar, $\mathrm{n}=9$ ) and the University of Brasília (UnB, n = 5).

Genetic material was extracted using the Wizard® Genomic DNA Purification kit (Promega) according to the maker's protocol. Part of the MC1R of each specimen was obtained using PCR reactions based on the following primers, described by Cheviron et al. (2006). We used standard methods described elsewhere (Carneiro et al. 2012, Luna et al. 2017) to amplify and obtain sequences for $M C 1 R$ in an $\mathrm{ABI} 3500 \mathrm{XL}$ autobmatic sequencer (Applied Biosystems).

The alignment and possible correction of the codification of the observed insertions and deletions were run in the Bioedit sequence editor (Hall 1999). All the sequences generated in the present study were deposited in GenBank (www.ncbi.nlm. nih.gov) under access numbers MG601527 through MG601534 (Table I).

\section{GENETIC ANALYSIS}

The MC1R sequences obtained were aligned with those available in GenBank for the species 
TABLE I

List of the species analyzed in the present study with the identification code of each specimen, the variable sites identified in the genus Antilophia and the sites (marked in gray) that have been associated with melanic phenotypes in birds. The asterisks indicate sequences equal to the initial sequence (specimen AboCAA01). Heterozygous sites are denominated by a standardized letter code established by IUPAC $(R=C / T)$. A genotype is a combination of two alleles. Genotype codes used in the Network program. GenBank access numbers for the samples analyzed.

\begin{tabular}{|c|c|c|c|c|c|c|c|c|c|c|c|c|c|c|}
\hline \multirow{4}{*}{$\begin{array}{l}\text { Species } \\
\text { (plumage) }\end{array}$} & \multirow{4}{*}{ Sample codes } & \multicolumn{10}{|c|}{ Position sites $^{1}$ (vertical) } & \multirow{4}{*}{ Genotype } & \multirow{4}{*}{$\begin{array}{l}\text { Genotype codes } \\
\text { for Network }\end{array}$} & \multirow{4}{*}{$\begin{array}{c}\text { Access number } \\
\text { GenBank }\end{array}$} \\
\hline & & 1 & 2 & 2 & 2 & 2 & 3 & 5 & 6 & 6 & 6 & & & \\
\hline & & 8 & 0 & 4 & 5 & 7 & 2 & 2 & 2 & 8 & 9 & & & \\
\hline & & 9 & 7 & 4 & 3 & 4 & 8 & 9 & 9 & 9 & 5 & & & \\
\hline \multirow{16}{*}{$\begin{array}{l}\text { A. bokermanni } \\
\text { (white) }\end{array}$} & AboCAA01 & G & A & G & G & $\mathrm{G}$ & A & $\mathrm{C}$ & $\mathrm{C}$ & A & G & $1 / 1$ & H_1 & MG601527 \\
\hline & AboCAA02 & $*$ & $*$ & $*$ & $*$ & $*$ & $*$ & $*$ & $*$ & $*$ & $*$ & $1 / 1$ & H_1 & MG601527 \\
\hline & AboCLU01 & $*$ & * & $*$ & $*$ & $*$ & $*$ & * & $*$ & * & * & $1 / 1$ & H_1 & MG601527 \\
\hline & AboCLU02 & * & * & $*$ & $*$ & $*$ & $*$ & * & * & * & * & $1 / 1$ & H_1 & MG601527 \\
\hline & AboCLU03 & $*$ & $*$ & $*$ & $*$ & $*$ & $*$ & $*$ & $*$ & $*$ & $*$ & $1 / 1$ & H_1 & MG601527 \\
\hline & AboCLU04 & $*$ & $*$ & $*$ & $*$ & $*$ & $*$ & $*$ & $*$ & $*$ & $*$ & $1 / 1$ & H_1 & MG601527 \\
\hline & AboCLU05 & $*$ & $*$ & * & $*$ & $*$ & $*$ & $*$ & $*$ & $*$ & $*$ & $1 / 1$ & H_1 & MG601527 \\
\hline & AboCVV01 & $*$ & $*$ & $*$ & $*$ & $*$ & $*$ & $*$ & $*$ & $*$ & $*$ & $1 / 1$ & H_1 & MG601527 \\
\hline & AboBCE01 & $*$ & $*$ & $*$ & $*$ & $*$ & $*$ & $*$ & $*$ & $*$ & $\mathrm{~T}$ & $2 / 2$ & H_3 & MG601529 \\
\hline & AboBCE02 & $*$ & $*$ & $*$ & $*$ & $*$ & $*$ & $*$ & $*$ & $*$ & $*$ & $1 / 1$ & H_1 & MG601527 \\
\hline & AboBCE03 & $*$ & $*$ & A & $*$ & $*$ & $\mathrm{~T}$ & $*$ & $*$ & $*$ & $*$ & $3 / 3$ & H_2 & MG601528 \\
\hline & AboBME01 & $*$ & $*$ & $*$ & $*$ & * & $*$ & $*$ & $*$ & $*$ & $*$ & $1 / 1$ & H_1 & MG601527 \\
\hline & AboBME02 & $*$ & $*$ & $*$ & $*$ & $*$ & $*$ & $*$ & $*$ & $*$ & $*$ & $1 / 1$ & H_1 & MG601527 \\
\hline & AboBME03 & $*$ & $*$ & $*$ & $*$ & $*$ & $*$ & $*$ & $*$ & $*$ & $*$ & $1 / 1$ & H_1 & MG601527 \\
\hline & AboMHE02 & $*$ & $*$ & $*$ & $*$ & * & * & $*$ & $*$ & $*$ & $*$ & $1 / 1$ & H_1 & MG601527 \\
\hline & AboMFU01 & $*$ & $*$ & $*$ & $*$ & $*$ & * & $*$ & $*$ & $*$ & $*$ & $1 / 1$ & H_1 & MG601527 \\
\hline \multirow{14}{*}{$\begin{array}{l}\text { A. galeata } \\
\text { (black) }\end{array}$} & Aga39 & $*$ & $*$ & $*$ & $*$ & $*$ & $*$ & $*$ & $*$ & $*$ & $*$ & $1 / 1$ & H_1 & MG601530 \\
\hline & Aga40 & $*$ & $*$ & $*$ & $*$ & $*$ & $*$ & $*$ & $*$ & $*$ & $*$ & $1 / 1$ & H_1 & MG601530 \\
\hline & Aga41 & $*$ & $*$ & $*$ & $*$ & $*$ & $*$ & $*$ & $*$ & $*$ & $*$ & $1 / 1$ & H_1 & MG601530 \\
\hline & Aga42 & $*$ & $*$ & $*$ & $*$ & $*$ & $*$ & $*$ & $*$ & $*$ & $*$ & $1 / 1$ & H_1 & MG601530 \\
\hline & Aga43 & A & $*$ & $*$ & $*$ & $*$ & $*$ & $*$ & $*$ & $*$ & $*$ & $4 / 4$ & H_4 & MG601531 \\
\hline & Aga410 & $*$ & $*$ & $*$ & $*$ & $*$ & $*$ & $*$ & $*$ & $*$ & $*$ & $1 / 1$ & H_1 & MG601530 \\
\hline & Aga519 & $*$ & $*$ & $*$ & $*$ & $*$ & $*$ & $*$ & $\mathrm{R}$ & $*$ & $*$ & $1 / 5$ & H_6 & MG601533 \\
\hline & Aga545 & $*$ & $*$ & $*$ & $*$ & $*$ & $*$ & $*$ & $*$ & $*$ & $*$ & $1 / 1$ & H_1 & MG601530 \\
\hline & Aga761 & $*$ & $*$ & $*$ & $*$ & $*$ & $*$ & $*$ & $\mathrm{~T}$ & $*$ & $*$ & $5 / 5$ & H_5 & MG601532 \\
\hline & Aga795 & $*$ & $*$ & * & * & $*$ & $*$ & $\mathrm{~T}$ & $*$ & $*$ & $*$ & $6 / 6$ & H_7 & MG601534 \\
\hline & Aga822 & $*$ & $*$ & $*$ & $*$ & $*$ & $*$ & $*$ & $*$ & $*$ & $*$ & $1 / 1$ & H_1 & MG601530 \\
\hline & Aga906 & $*$ & $*$ & $*$ & $*$ & $*$ & $*$ & $*$ & $*$ & $*$ & $*$ & $1 / 1$ & H_1 & MG601530 \\
\hline & Aga1010 & $*$ & $*$ & $*$ & $*$ & $*$ & $*$ & $*$ & $*$ & $*$ & $*$ & $1 / 1$ & H_1 & MG601530 \\
\hline & Aga1130 & $*$ & $*$ & $*$ & $*$ & $*$ & $*$ & $*$ & $*$ & $*$ & $*$ & $1 / 1$ & H_1 & MG601530 \\
\hline
\end{tabular}

${ }^{1}$ Nucleotide sequences numbered according to their position in the MC1R sequence of the chicken $(G$. gallus - access number NM_001031462). 


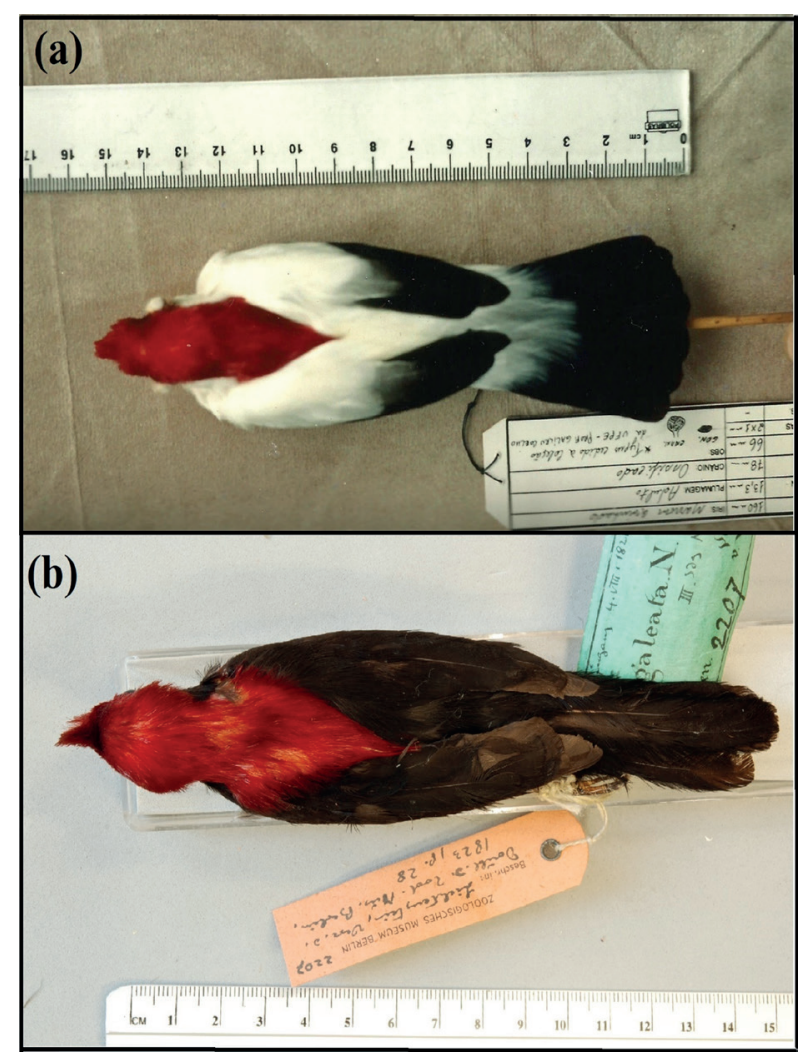

Figure 1 - Dorsal view of the holotypes of (a) Antilophia bokermanni (No. 1130 - Ornithological Collection of the Universidade Federal do Pernambuco, Recife) and (b) Antilophia galeata (ZMB\#2207 - Ornithological Collection of the Zoologisches Museum, Berlin).

Lepidothrix coronata (access numbers DQ388308 and DQ388310), L. serena (DQ388331), and Gallus gallus (NM_001031462). This comparative analysis permitted the identification of variation in the sites of nucleotides known to be associated with melanic plumage in birds.

The genotype network was prepared using the maximum likelihood method in Haploviewer (Salzburguer et al. 2011). Fu's Fs test (Fu 1997) was applied to evaluate the distribution of the genotype frequencies in comparison with that expected according to a neutral model, while Tajima's $D$ (Tajima 1989) was used to assess the difference between the number of segregating sites and the mean number of nucleotide differences, which were calculated in DNAsp 5.1 (Librado and Rozas

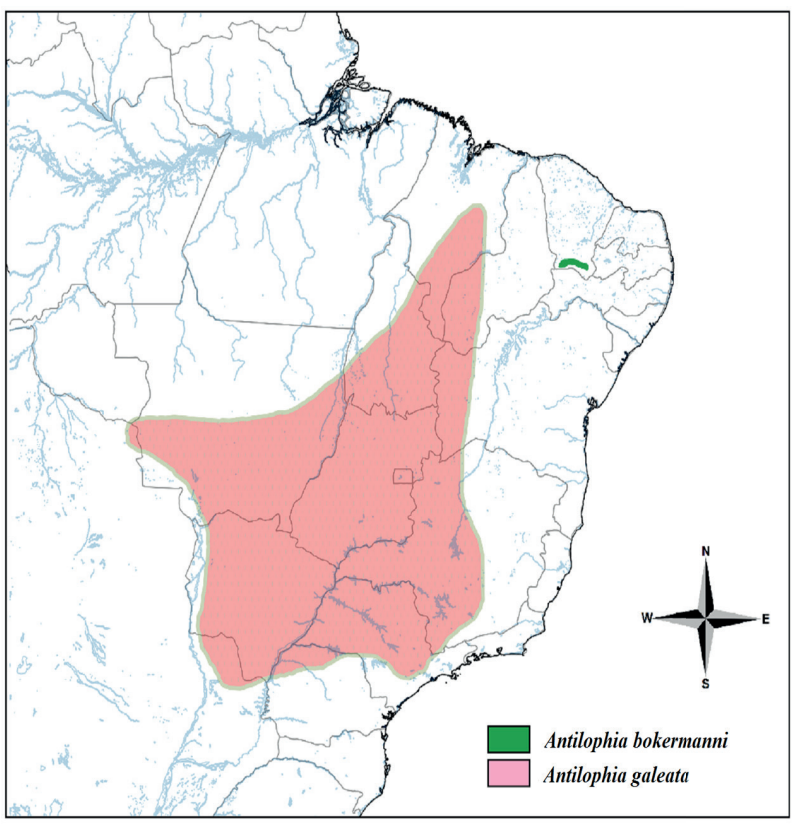

Figure 2 - Geographic distribution of $A$. bokermanni and A. galeata. The geographic ranges of the two species were adapted from NatureServe.

2009). The McDonald-Kreitman test (McDonald and Kreitman 1991) was used to examine the possible occurrence of positive selection, and to identify putative sites of functional importance in the two species (these analyses were also run in DnaSP).

\section{RESULTS AND DISCUSSION}

No evidence was found of selection or association between the mutations of the MC1R gene and the melanic variation in Antilophia. This reinforces the findings of previous studies, which found no association between phenotypic differences and the variation in the $M C 1 R$ gene (Cheviron et al. 2006, Haas et al. 2009, Bourgeois et al. 2012), which rejects our first hypothesis, that changes in this codifying region may determine the differences in the melanic coloration of $A$. galeata and $A$. bokermanni.

In the present study, 702 base pairs, corresponding to positions $156-858$ of the 945 


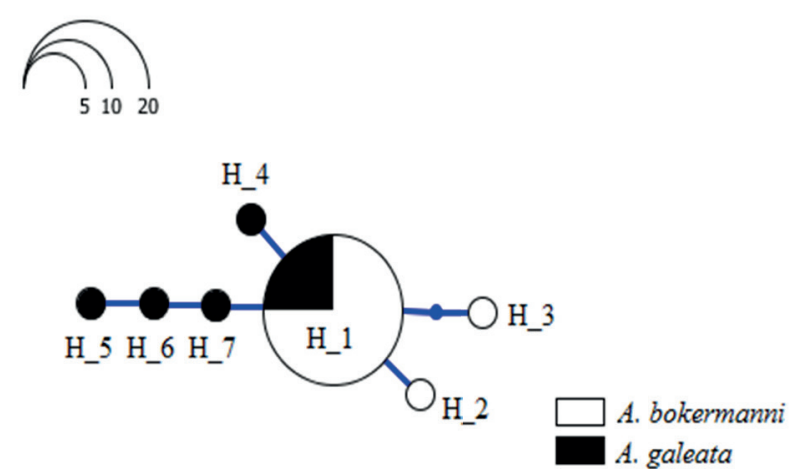

Figure 3 - Genotype network generated from the sequences of the MC1R generated in the present study for A. bokermanni and $A$ galeata. The genotypes are represented by circles, the size of which is proportional to their frequency. The white shading represents the samples of $A$. bokermanni and black shading, the samples of $A$. galeata.

base pairs of the MC1R sequence of G. gallus, were sequenced (Kerje et al. 2003). Ten sites were polymorphic, providing a total of six $M C 1 R$ alleles in Antilophia. All the variable MC1R sites known to be associated with melanic patterns were conserved in the Antilophia specimens analyzed here (see the gray shaded column in Table I: the numeration corresponds to that of the $M C 1 R$ sequence of $G$. gallus: Kerje et al. 2003). While non-synonymous mutations were recorded in some specimens, they were not shared by other individuals of the same species. In addition, the fact that the $\mathrm{H}_{-} 1$ genotype was found at high frequencies in both species (Figure 3) confirms the lack of any systematic influence of the $M C 1 R$ on the distinct plumage patterns. These findings indicate that the changes in the $M C 1 R$ gene may not have resulted in functional changes in the expression of the melanic coloration found in Antilophia. A similar situation was observed by Uy et al. (2009) in the Chestnutbellied monarch, Monarcha castaneiventris, from the Solomon Islands.

In the case of Antilophia, this alternative mechanism may have arisen from changes in the interaction of the $M C 1 R$ gene with associated regulator pathways. The alterations in these mechanisms may have resulted in the differential expression of the coloration pattern in the closelyrelated Antilophia species (Cone et al. 1996, Steiner et al. 2007, Manceau et al. 2011). In the specific case of $A$. bokermanni, this would account for the restriction of the black pigment to the flight feathers (Figure 1).

Due to the intense sexual selection that is characteristic of the manakins, the coloration of the male plumage tends to evolve rapidly and independently, with little convergence among taxa (Prum 1997). In the context of the very recent divergence of the two Antilophia species (Luna et al. 2017), a small population, such as that of $A$. bokermanni, would be subject to intense selection pressures due to its isolation, which may have contributed to the rapid fixation of a new plumage coloration pattern. The achromatic variation and that in the brilliance of the plumage may be one of the most important attributes determining female mate choice and competition between males (Doucet et al. 2005, Stein and Uy 2006, Laczi et al. 2011). However, it is still necessary to determine the role of these plumage characteristics in the reproductive success of these species, in particular in A. bokermanni.

Even so, the changes in the pattern of melanic coloration may be associated with a number of different selection pressures. In the present study, the results of the neutrality tests for the MC1R sequences did not contradict the hypothesis that the gene may be evolving in a neutral fashion. The values of Fu's $F s$ and Tajima's $D$, calculated for each species, found no evidence of non-neutral variation in either A. bokermanni ( $D:-1.6965$ and Fs: $-0,5109 ; \mathrm{p}>0.05)$ or A. galeata (D: -1.2782 and $\left.F_{S}:-0,5109, \mathrm{p}>0.05\right)$.

The result of the McDonald-Kreitman (MK) test did not indicate any evidence of evolutionary adaptation, given that none of the mutations were fixed, even though the majority were nonsynonymous in relation to the amino acids codified. This reinforces the conclusion that the variability 
found in the $M C 1 R$ gene was not the result of functional changes, but rather that there has been some differential modification in the regulatory mechanism of its interaction with the melanin receptors it controls in the two Antilophia species.

\section{ACKNOWLEDGMENTS}

This study was supported by the Conselho Nacional de Desenvolvimento Científico e Tecnológico (CNPq), Universal project (460195/2014$0)$; the Universidade Federal do Pará, through the Associação de Pesquisa e Preservação de Ecossistemas Aquáticos, Museu Paraense Emílio Goeldi and the Instituto de Estudos Costeiros, together with the Post Graduate Program in Environmental Biology and the Post Graduate Program in Zoology. Sample collection was authorized by the Instituto Brasileiro do Meio Ambiente e dos Recursos Naturais Renováveis (license no. 027/2005). We thank Marcos Raposo, curator of the ornithological collection of the National Museum, for photographs of the Antilophia galeata holotype. We also acknowledge the collaboration of the following institutions: Universidade Federal de São Carlos (UFSCar), Universidade de Brasília (UnB) and Museu Paraense Emílio Goeldi, for providing samples for this study.

\section{REFERENCES}

BOURGEOIS YXC, BERTRAND JAM, THÉBAUD C AND MILÁ B. 2012. Investigating the Role of the Melanocortin-1 Receptor Gene in an Extreme Case of Microgeographical Variation in the Pattern of MelaninBased Plumage Pigmentation. PLoS ONE 7: 1-8.

CARNEIRO LS, GONZAGA LP, RÊGO PS, SAMPAIO I, SCHNEIDER H AND ALEIXO A. 2012. Systematic revision of the spotted anppitta (Grallariidae: Hylopezus macularius), with description of a new species from Brazilian Amazonia. Auk 129: 338-351.

CHEVIRON ZA, HACKETT SJ AND BRUMFIELD RT. 2006. Sequence variation in the coding region of the melanocortin-1 receptor gene $(M C 1 R)$ is not associated with plumage variation in the blue-crowned manakin
(Lepidothrix coronata). Proc R Soc Lond B Biol Sci 273 : 1613-1618.

COELHO AGM AND SILVA WAG. 1998. A new species of Antilophia (Passeriformes: Pipridae) from Chapada do Araripe, Ceará, Brasil. Ararajuba 6: 81-84.

CONE RD, LU D, KOPPULA S, VAGE DI, KLUNGLAND H, BOSTON B, CHEN W, ORTH DN, POUTON C AND KESTERSON RA. 1996. The melanocortin receptors: agonists, antagonists, and the hormonal control of pigmentation. Recent Prog Horm Res 51: 287-317.

DOUCET SM. MENNILL DJ, MONTGOMERIE R, BOAG PT AND RATCLIFFE LM. 2005. Achromatic plumage reflectance predicts reproductive success in male blackcapped chickadees. Behav Ecol 16: 218-222.

DUNN PO, ARMENTA JK AND WHITTINGHAM LA. 2015. Natural and sexual selection act on different axes of variation in avian plumage color. Sci Adv 1: e1400155.

FU YX. 1997. Statical test of neutrality of mutations agains population growth, hitchhinking and background selection. Genetics 147: 915-925.

HAAS F, POINTER MA, SAINO N, BRODIN A, MUNDY NI AND HANSSON B. 2009. An analysis of population genetic differentiation and genotype-phenotype association across the hybrid zone of carrion and hooded crows using microsatellites and MC1R. Mol Biol Evol 18: 294-305.

HALL TA. 1999. BIOEDIT: a user-friendly biological sequence alignment editor and analysis program for Windows 95/98/ NT. Nucleic Acids Symp Ser 41: 95-98.

KERJE S, LIND J, SCHUTZ K, JENSEN P AND ANDERSSON L. 2003 Melanocortin 1-receptor $(M C 1 R)$ mutations are associated with plumage colour in chicken. Anim Genet 34: 241-248.

LACZI M, TÖRÖK J, ROSIVALL B AND HEGYI G. 2011. Integration os spectral reflectance across the plumage: Implications for mating patterns. PLoS ONE 6: e23201.

LIBRADO P AND ROZAS J. 2009. DnaSP v5: A software for comprehensive analysis of DNA polymorphism data. Bioinfo 25: 1451-1452.

LUNA LW, SOUZA TO, CARNEIRO LS, SILVA WAG, SCHNEIDER H, SAMPAIO I, ARARIPE J AND RÊGO PS. 2017. Molecular data and distribution dynamics indicate a recent and incomplete separation of manakins species of the genus Antilophia (Aves: Pipridae) in response to Holocene climate change. J Avian Biol 48: 1177-1188.

MANCEAU M, DOMINGUES VS, MALLARINO R AND HOEKSTRA HE. 2011. The Developmental Role of Agouti in Color Pattern Evolution. Science 331(6020): 1062-1065.

MCDONALD JH AND KREITMAN M. 1991. Adaptive protein evolution at the Adh locus in Drosophila. Nature 351: 652-654. 
MUNDY NI. 2005. A window on the genetics of evolution: $M C 1 R$ and plumage colouration in birds. Proc R Soc Lond B Biol Sci 272: 1633-1640.

PRUM RO. 1997. Phylogenetic tests of alternative intersexual selection mechanisms: Trait macroevolution in a polygynous clade (Aves: Pipridae). Am Nat 149: 668-692.

RÊGO PS, ARARIPE J, SILVA WAG, ALBANO C, PINTO T, CAMPOS AA, VALLINOTO M, SAMPAIO I AND SCHNEIDER H. 2010. Population genetic studies of mitochondrial pseudo-control region in the endangered araripe manakin (Antilophia bokermanni). Auk 127(2): 335-342.

ROULIN A AND DUCREST AL. 2013. Genetics of colouration in birds. - Semin. Cell Dev Biol 24: 594-608.

SALZBURGER W, EWING GB AND VON HEASELER A. 2011. The performance of phylogenetic algorithms in estimating haplotype genealogies with migration. Mol Ecol 20: 1952-1963.

STEIN AC AND UY JAC. 2006. Plumage brightness predicts male mating success in the lekking golden-collared manakin, Manacus vitellinus. Behav Ecol 17: 41-47.

STEINER CC, WEBER JN AND HOEKSTRA HE. 2007. Adaptive variation in beach mice produced by two interacting pigmentation genes. PLoS Biol 5: 1880-1889.

TAJIMA F. 1989. Statistical method for testing the natural mutation hypothesis by DNA polymorphism. Genetics 123: 585-595.

UY JAC, MOYLE RG, FILARDI CE AND CHEVIRON ZA. 2009. Difference in Plumage Color Used in Species Recognition between Incipient Species Is Linked to a Single Amino Acid Substitution in the Melanocortin-1 Receptor. Am Nat 174: 244-254. 